\title{
Effect of Addition of Pomegranate Peel in the Ration with or Without Polyethylene Glycol on Productive Performance of Lactating Goats
}

\author{
Abd El-Kader Mahmoud Kholif ( $\nabla$ am_kholif2000@yahoo.co.uk ) \\ National Research Centre https://orcid.org/0000-0001-8207-6460 \\ Gamal Eldeen Aboulfotouh \\ Fayoum University Faculty of Agriculture \\ Ola Gamal Ahmed Hassan \\ Fayoum University Faculty of Agriculture \\ Abdelalim Mohamed Abd El-Mola \\ El Fayom University Faculty of Agriculture: Fayoum University Faculty of Agriculture
}

\section{Research Article}

Keywords: Pomegranate peel, polyethylene glycol, Lactating Zaraibi goats, feed intake, nutrients digestibility, milk yield and feed conversion.

Posted Date: July 27th, 2021

DOI: https://doi.org/10.21203/rs.3.rs-718747/v1

License: (c) (i) This work is licensed under a Creative Commons Attribution 4.0 International License. Read Full License 


\section{Abstract}

Pomegranate juice processing industries generate enormous waste in the form of peel that has been suggested and evaluated as a supplement in animal feed but pomegranate peel have high percent of tannins, So the purpose of this paper was to estimate the effect of addition of pomegranate peel (PP), detanninated pomegranate peel (DPP) and pomegranate peel with polyethylene glycol (PEG) on nutrients digestibility, goats milk yield and its composition, feed conversion and some blood parameters. Also, simple economic evaluation of the tested rations was considered.Sixteen lactating Zaraibi goats of about 3-4 years old (in their $2^{\text {nd }}$ to $4^{\text {th }}$ of lactation seasons with an average body weight of about $25+0.5 \mathrm{~kg}$ were used in the present study. After 14 days of parturition was randomly assigned into four groups, four animals per each tested ration (R) for 90 days, $\mathbf{R}_{\mathbf{1}}$ : Control : $50 \% \mathrm{CFM}+25 \%$ Egyptian clover and $25 \%$ wheat straw, $\mathbf{R}_{\mathbf{2}}$ : Control ration $+1 \% \mathrm{PP}, \mathbf{R}_{\mathbf{3}}$ : Control ration $\mathbf{+ 1} \% \mathrm{PP}+20 \mathrm{~g}(\mathrm{PEG})$ and $\mathbf{R}_{\mathbf{4}}$ :Control ration $\mathbf{+ 1} \%$ DPP. The results revealed that the PP contained 90.85\% DM, 4.84\% CP, 15.53\% CF, 87.21\%OM, 4.69\% EE, 62.15\% NFE and $15.28 \%$ tannins. No significant differences were found between the tested rations regarding nutrients digestibility except $E E$ digestibility. Nutritive values of $R_{2}$ and $R_{3}$ were slightly higher than $R_{4}$ and $R_{1}$, respectively. Ration three $\left(R_{3}\right)$ was the best ration for daily milk yield and total milk yield, where $R_{4}$ showed the worst one. Also, there are no significant differences for dry matter, SV and TDN intake. While, values of DCP intake were higher significantly $(P<0.05)$, for $R_{3}$ and $R_{2}$ followed by $R_{4}$ then $R_{1}$. Regarding feed conversion, $R_{4}$ was superior to other tested rations followed by $R_{1}$ then $R_{3}$ followed by $R_{2}$. All blood serum parameters were in the normal rang which support that the healthy effect of tested additives in goats rations. It seems that $R_{2}$ and $R_{3}$ could be used successfully for lactating goats, but $R_{3}$ is very expensive from economical point of view, where $\mathrm{R}_{3}$ was negatively economical effect, and not recommended.

\section{Introduction}

Pomegranate (Punica granatum L.) belongs to the Punicaceae family (Miguel et al., 2010) and is popularly consumed as fresh fruit, drinks, food items and extracts that are used in herbal remedies and dietary supplements as botanical ingredients. Fruit (peel, seeds and juice) is the main source of dietary pomegranate phytochemicals (Mars and Marrakchi, 1999). Pomegranate peel can be regarded as a waste from the pomegranate industry, producing comparatively higher polyphenol levels compared to fruit juice or seeds and flower fractions (Sestili et al ., 2007).

The presence of high molecular weight phenolics, ellagitannins, proanthocyanidins, complex polysaccharides, flavonoids and substantial amounts of microelements that have good anti-mutagenic, antioxidant, antimicrobial and apoptotic properties in general is characterised by pomegranate peel, which accounts for around 50 percent of fruit weight (Prakash et al ., 2013).

The average area under pomegranates amounted to 85.676 thousand Fadden representing $5.1 \%$ of the average area under fruit crops in Egypt over 2016/2017. Also average production of pomegranates amounted to 381 thousand ton in 2016/2017 according to Central Agency for Public Mobilization and Statistics. (2019). Pomegranate peel represents $50-67 \%$ of the total weight of pomegranate fruit according 
to Christaki et al. )2011( and Prakash and Prakash )2011), so average production of pomegranates peel amounted to190.5- 255.27thousand ton in 2016/2017.

Hussein and Shujaa (2013a) and HamaKhan et al. (2015) showed that effect of antioxidant levels in pomegranate peel in lambs fed helps to improve their health and animal performance. Also, Abarghuei et al., (2013) indicated that cows fed $800 \mathrm{ml}$ pomegranate peel extract in their diet were significantly increased in milk yield.

High intakes of tannins have a direct negative impact on productivity; the availability of nutrients is reduced due to the complexes formed between tannins and many forms of macromolecules, voluntary consumption of feed and digestibility are reduced, the animal's digestive physiology may be compromised, and mucosal disturbances may occur, etc. (Addisu, 2016), but, In any case, it is increasingly recognised that the quantity consumed is important because tannins in many forage types can have beneficial effects in moderate quantities (Waghorn and Mcnabb, 2003).

Polyethylene glycol (PEG) is a polymer that irreversibly binds tannins, reducing the harmful food intake effects of tannins (Silanikove et al., 1994), digestibility (Silanikove et al., 1996), and preferences (Titus et al., 2001). So we used detanninated pomegranate peel and polyethylene glycol ( PEG) as a tannin-binding agent in current research to decrease the impact of polyphenolic compounds.

The purpose of this research was to estimate the effect of addition of pomegranate peel (PP), detanninated pomegranate peel (DPP) and pomegranate peel with polyethylene glycol (PEG) on nutrients digestibility, goats milk yield and its composition, feed conversion and some blood parameters. Also, simple economic evaluation of the tested rations was considered.

\section{Materials And Methods}

The present research was carried out at the Experimental Farm and Laboratories of Animal Production Department - Faculty of Agriculture - Fayoum University, Egypt, during April to June, 2019.

\section{Preparation of pomegranate peel and detanninated pomegranate peel}

Dried pomegranate peels were acquired from the by-product unites in Fayoum, Egypt. Peels were crushed in a grinder to reduce it to coarse size peel. Detanninated pomegranate peel prepared according to (Kushwaha et al., 2013), Both detanninated and dried pomegranate peel powder transferred in polyethylene bags for chemical analysis and in farm trial.

\section{Polyethylene glycol (PEG) source}

Polyethylene glycol 4000 produced by Chem-Lab NV, Industriezone "De Arend" 2, Belgium.

\section{Experimental animals}


Sixteen lactating Zaraibi goats of about 3-4 years old (in their 2nd to 4th lactation seasons) with an average body weight of about $25+0.5 \mathrm{~kg}$ were used in the present study. After 14 days of parturition was randomly assigned into four groups, four animals per each tested ration $(R)$ using complete randomized design.

\section{The tested rations:-}

The goats were individually fed rations of concentrate: roughage at ratio of 1:1 on DM basis. The concentrate feed mixture consisted of $60 \%$ yellow corn, $20 \%$ soybean meal, $17.5 \%$ wheat Bran, $1.5 \%$ limestone, $0.2 \%$ dicalcium phosphate, $0.3 \%$ premix and $0.5 \% \mathrm{NaCl}$, where, Four tested rations were used in this experiment as shown below: $\mathbf{R}_{\mathbf{1}}$ : Control : $50 \% \mathrm{CFM}+25 \%$ Egyptian clover and $25 \%$ wheat straw, $\mathbf{R}_{\mathbf{2}}$ : Control ration $+1 \%$ pomegranate peel, $\mathbf{R}_{\mathbf{3}}$ : Control ration $+1 \%$ pomegranate peel $+20 \mathrm{~g}$ Polyethylene glycol (PEG) and $\mathbf{R}_{\mathbf{4}}$ : Control ration $+1 \%$ detanninated pomegranate peel.

\section{Feeding and management of animals:-}

Animals were fed to cover their nutritional requirements according to NRC (1985). The concentrate feed mixture was offered with wheat straw daily at $8.00 \mathrm{am}$., then Egyptian clover offered once daily at $4.00 \mathrm{pm}$. The $1 \%$ pomegranate peel $1 \%$ pomegranate peel $+20 \mathrm{~g}$ polyethylene glycol (PEG) and $1 \%$ detanninated pomegranate peel were introduced daily to each animal of second, third and fourth group with the concentrate feed mixture. Fresh water was available to the animals all the time. The experimental period was extended to 90 days.

\section{Digestibility trial:}

Digestibility trial was performed at the end of the lactation experiment, the nutrient digestibilities and feeding values were determined using acid insoluble ash (AIA) technique of Van Keulen and Young (1977). Feces samples were collected daily per each animal for seven days, dried overnight in hot air oven at $60^{\circ} \mathrm{C}$, weighted, ground through $1 \mathrm{~mm}$ screen, then complete drying was undertaken at $105^{\circ} \mathrm{C}$ for $3 \mathrm{hrs}$ and weighted and stored in tight bottles for chemical analysis according to $\mathrm{AOAC}(2009)$.

\section{Lactation trial:-}

After 14 days of the goat's parturition, milk yield was recorded during the last three days of each month for three months. Goats have been milked (hand milking) twice daily at 7:00 am and 7:00 pm by milking one teat while, the other one was lift to lamb for suckling according to Farag (1979). Milk samples were stored in bottles $(100 \mathrm{ml})$ and frozen at $\left(-20^{\circ} \mathrm{C}\right)$ till the chemical analysis.

\section{Sampling of blood:-}

Blood samples were collected at the end of lactation trial (90 day) before morning feeding. A sample of 10 $\mathrm{ml}$ of blood per animal was collected from the jugular vein in dry clean glasses tubes. Blood samples were centrifuged for 20 minutes at $3500 \mathrm{rpm}$ to obtain serum. Serum was separated into a clean dried glass vial and stored at $-18^{\circ} \mathrm{C}$ for chemical analysis.

\section{Methods of analysis:-}




\section{Feeds and feces analysis:-}

Chemical analysis of feedstuffs and feces samples were carried out to determine the percentage of dry matter (DM), crude protein (CP), ether extract (EE), crude fiber (CF) and ash content according to methods of AOAC (2009). The nitrogen free extract (NFE) was calculated by difference. Neutral detergent fiber (NDF), acid detergent fiber (ADF) and acid detergent Lignin (ADL) were determined according to Goering and Van Soest (1970). The tannin contents were determined by Folin Denis reagent as described by Makkar et al. (1993).

\section{Milk analysis:}

The Chemical analysis of milk samples were determined according to AOAC (2009), The free radical scavenging activity of milk samples was measured using DPPH (1,1 diphenyl 2, picryl hydrazyl) assay (Brand-Williams et al., 1995), and Fat corrected milk (4\% FCM) was calculated by using the following equation according to Gaines (1928): $F C M=0.4 \mathrm{M}+15 \mathrm{~F}$

Where: $\mathrm{M}=$ milk yield $(\mathrm{g} / \mathrm{d}), \mathrm{F}=$ fat yield (amount of fat $=\mathrm{M} \times$ fat $\%$ ).

\section{Blood serum analysis}

Serum protein, albumin, urea, aspartate aminotransferase (AST), alanine aminotransferase (ALT), glucose, creatinine, cholesterol, tri-glycerides and HDL concentration were determined using specific kits (Stanbio Laboratory, Boerne, TX, USA) following manufacturer instructions.

\section{Statistical analyses:}

Statistical analyses were conducted by the general linear model procedure adapted by SPSS (2007) according to the following model:

$Y_{i j}=\mu+T_{i}+e_{i j}$

Where: $Y_{i j}$, is the dependent variable, $\mu$ is the overall mean, $T_{i,}$, is the effect of treatment and $e_{i j}$, is the residual error. Duncan's multiple test (Duncan, 1955) was carried out to separate among means.

\section{Simple economic evaluation}

Economic return of the tested rations were calculated assuming that the price of one $\mathrm{kg}$ of raw milk was 7

L.E. and the cost of one ton DM of Egyptian clover, corn, wheat bran, soybean meal, wheat straw and Pomegranate Peel were $2500,4100,3900,6700,1000$, and 500 L.E, respectively and the price of one $\mathrm{Kg}$ Polyethylene glycol was 950 L.E.

\section{Results And Discussion}

\section{Chemical composition of feed ingredients}


Chemical composition of feed ingredients is presented in Table (1). The detanninated pomegranate peel (DPP) contained lower OM (84.12\%), EE (1.62\%), NFE (57.72\%) and tannins (14.65\%) compared with dried pomegranate peel (PP), while DPP recorded higher content of DM $(96.75 \%), \mathrm{CP}(5.89 \%), \mathrm{CF}(18.87 \%)$, NDF (30.10\%), ADF (29.17\%), ADL (12.09\%), hemicelluloses (1.82\%), cellulose (17.07\%) and lignin ( $6.89 \%)$ than PP.

Chemical constituents of dried peels are nearly similar to the outcoms of Taher-Maddah et al. (2012), Kushwaha et al. (2013) and Sadq et al. (2015). On the other hand, some variations are founded between chemical compositions of PP in the present research in comparison to those shown by Mirzaei-Aghsaghali et al., (2011), Ebrahimi (2012) and Delavar et al., (2014). These variations in the chemical constitution of PP is possibly caused by dissimilar unique materials, growing conditions (geographic, seasonal differences, climatic changes, and land properties). Chemical compositions of DPP were in agreement with Kushwaha et al., (2013), which they reported that DM (17.63\%), ash (3.29\%), EE (1.43\%), CP (6.43\%), CF (24.36\%), NDF (28.54\%), ADF (26.11\%) and lignin (7.59\%). Higher chemical compositions in DPP than PP indicated that retention and accumulation of the above compositions during the detannination process but in case of lower test values in DPP than PP indicated that losses of the above components during the detannination process. The summative analysis of concentrate feed mixture; Egyptian clover and wheat straw were in the common range.

\section{Digestibility and nutritive values of tested rations}

Date in Table (2) presented the average values of digestibility coefficients and nutritive values of the tested rations. No significant differences were found between the tested rations regarding nutrients digestibility except EE digestibility, where $R_{2}, R_{3}$, and $R_{4}$ were superior to $R_{1}$. The result indicated that $C P$ and $C F$ digestibilies were the highest in $\mathrm{R}_{3}$ compared to other treatment groups. Furthermore, the mean value of $\mathrm{OM}$ and $E E$ digestibilies were the highest value was found in $R_{2}$. Also, $D M$ digestibility was higher value in $R_{2}, R_{3}$, and $R_{1}$ than $R_{4}$. While, NFED showed higher digestibility in control group $\left(R_{1}\right)$ followed by $R_{2}, R_{3}$, and $R_{4}$.

Hatami et al., (2018), Sadq et al. (2015) and Jami et al. (2012) found that using pomegranate peel improved the digestibility of nutrients in diets compared to the control treatment. These researchers pointed out that improvement in digestibility might be due to the added nutritive value of the PP extract itself and low and moderate $(2 \%-4.5 \%)$ concentrations of condensed tannins in the diet improved production efficiency in ruminants, by increasing the flow of non-ammonia nitrogen and essential amino acids from the rumen. In ruminants, a particularly important positive effect of tannins is dietary protein protection from ruminal microflora attack (McNabb et al. 1996). The high digestibility of ether extract (EED) was found in lambs fed $4 \% \mathrm{PP}$, due to tannin was protected the ether extract to degrade in the rumen and it escapes and flow rate from rumen into the small intestine and it is more suitable for absorption (Patra and Saxena, 2011). These findings may support the obtained results of EE digestibility.

In contrast, Karamnejad et al. (2019), Shaani et al., (2015), Eliyahu et al., (2015), that found feeding PP containing diets caused a decrease in $\mathrm{DM}, \mathrm{OM}$, and $\mathrm{CP}$ digestibility compared to the control. Also, Abarghuei et al. (2013) reported that dietary inclusion of tannin- rich pomegranate peel extract (up to $1200 \mathrm{mg} / \mathrm{day}$ ) had no effect on the digestibility of DM, OM, NDF, and ADF in dairy cows. The inconsistency among these 
works may be associated with differences among studies, in the diets used as well as the differences in the amount and type of pomegranate (i.e., the concentration and nature of the active ingredients), and type of experimental animals, all which can affect digestibility.

Data in Table (2) cleared that no significant differences were obtained between the tested rations for SV, TDN, DCP, DE, ME and $\mathrm{NE}_{\mathrm{L}}$.

The $R_{2}$ and $R_{3}$ were recorded slightly higher of $S V, T D N$, and DCP than $R_{4}$ and $R_{1}$. The increases in TDN, SV, and $D C P$ value for $R_{2}$ and $R_{3}$ may reflect the results of digestibility coefficients of $C P, E E, C F$, and NFE.

Digestible energy (DE), metabolizable energy $(M E)$ and net energy for lactation $\left(N E_{L}\right)$ were deceased with $R_{1}$ and $R_{4}$ compared with $R_{2}$, and $R_{3}$. The results that obtained by Sadq et al. (2015) in this regard may support our findings they found that the higher TDN, DE, and ME are increased in lambs fed $1 \%$ PP compared to lambs fed 0,2 , and $4 \%$.

\section{Milk yield and milk composition}

Overall mean values of milk yield and composition are presented in Table (3). The $R_{3}$ was the best ratio for daily milk yield, where $R_{4}$ showed the worst one. Also, The $R_{3}$ recorded the highest values of FCM followed by $R_{4}$ then $R_{1}$ and finally $R_{2}$. There are significant differences $(p>0.05)$ for fat $\%$ and total solids $\%$ between the tested rations, where the ration four $\left(R_{4}\right)$ was the highest value compared with other rations. There are no significant differences $(p>0.05)$ for solids not fat $\%$, total protein $\%$ and lactose $\%$ between the tested rations, where the ration two $\left(R_{2}\right)$ was the highest value compared with other rations. Also, There are no significant effect $(p>0.05)$ for ash \% between the tested rations.

These results of daily milk yield and fat correct milk are agreement with those obtained by Safari et al., (2018) and Kotsampasi et al., (2017) who found that the diet containing pomegranate peel had no effect on milk yield and FCM. However, Shaani et al., (2015) reported that the addition of ensiled pomegranate pulp mixture (PPM) in the diet of cow decreased milk yield and increased $3.5 \%$ fat corrected milk (FCM) compared with the control. Moreover, Abarghuei et al., (2013) indicated that cows fed $800 \mathrm{ml}$ pomegranate peel extract in their diet were significantly increased in milk yield and FCM. Such differences may reflect the effect of animal breed and the differences in the amount and type of pomegranate.

This result is an agreement with the results of Alphonsus and Essien (2012) who found the same relationship between milk fat $\%$ and milk yield and the opposite relationship between milk total solids $\%$ and milk yield.

Safari et al., (2018) found that the supplementing diet containing pomegranate seed and peel significantly increased milk fat percent and milk fat yield dairy cows, and Shaani et al., (2015) reported that the addition of ensiled pomegranate pulp mixture (PPM) in the diet of cow increased milk fat percent. Such findings may support the obtained results. On the other hand Kotsampasi et al., (2017) who indicated that there were no effects of addition of pomegranate pulp silage on milk fat percent and milk fat yield of lactating dairy cows, 
Also Abarghuei et al., (2013) found that there is no effect of addition of $800 \mathrm{ml}$ pomegranate peel extract in the diet on milk fat percent, but there were significantly increased in milk fat yield.

These results of milk TS\%, and milk TS yield are agreement with those obtained by Kotsampasi et al., (2017) who indicated that there were no effects of addition of pomegranate pulp silage on milk TS\% and milk TS yield of lactating dairy cows, Also Abarghuei et al., (2013) indicated that there is no effect of addition of $800 \mathrm{ml}$ pomegranate peel extract in the diet on milk TS \%. Moreover, Shaani et al., (2015) and Safari et al., (2018) found that the supplementing diet containing pomegranate peel significantly increased milk TS\% and milk TS yield.

Such results nearly similar to that obtained by Safari et al., (2018) found that the supplementing diet containing pomegranate seed and peel significantly increased milk SNF \% and milk SNF yield of dairy cows. The contrast trend was found by Kotsampasi et al., (2017) indicated that the addition of pomegranate pulp silage on diet of lactating dairy cows decreased milk SNF \% and SNF yield.

Such results were followed the same trend obtained by Abarghuei et al., (2013), Kotsampasi et al., (2017) and Shaani et al., (2015) who indicated that there is no effect of addition of pomegranate peel in the diet on milk TP \% and milk TP yield, but Safari et al., (2018) found that the supplementing diet containing pomegranate seed and peel significantly increased milk TP \% and milk TP yield of dairy cows.

The obtained results were nearly similar to those obtained by Abarghuei et al., (2013) indicated that there is no effect of addition of 400, 800 and $1200 \mathrm{ml}$ pomegranate peel extract in the diet of dairy cows on milk lactose \% and milk lactose yield, Moreover Shaani et al., (2015) reported that the addition of ensiled pomegranate pulp mixture (PPM) in the diet of cow decreased milk lactose $\%$. These results expect $R_{4}$ contrast to those obtained by Safari et al., (2018) and Kotsampasi et al., (2017) who found that the supplementing diet containing pomegranate peel significantly increased milk lactose $\%$ and milk lactose yield.

These results are agreement with those obtained by Safari et al., (2018) found that there is no effect of the supplementing diet containing pomegranate seed and peel on milk ash \% and increased milk ash yield of dairy cows, but Kotsampasi et al., (2017) who reported that the addition 75 of pomegranate pulp silage in the diet of dairy cows decreased milk ash \% and there is no effect on milk ash yield.

Such finding differences may support the different animal breed and methodology of pomegranate prepared.

Data exhibited in Table (4) showed that overall mean values of milk yield and composition in the different lactation periods

Regarding the effect of milking period, data showed increasing milk yield and FCM from $P_{1}$ to $P_{\Pi}$ and then decreasing in $\mathrm{P}_{\mathrm{III}}$. There are significant differences for milk yield between periods of lactation for each ration. Period $\Pi$ showed the highest yield, but $P_{I I I}$ was the lowest one, Abedo et al., (2013) found the same trend with advance of lactation. Concerning the results of the effect of milking period on milk fat $\%$, it was 
clear that highest value significantly $(p \leq 0.05)$ was found with $P_{\mid}$and $P_{|| \mid}$compared to $P_{\| \mid}$. Such differences may also reflex the milk yield results, while there are no significant differences $(p>0.05)$ for milk fat yield.

Data showed that there are significant differences for milk total solids \% and milk total solids yield between periods of lactation, where the values of milk total solids $\%$ of $\mathrm{P}_{\Pi}$ and $\mathrm{P}_{I I I}$ were higher than $\mathrm{P}_{\mathrm{l}}$; and the value of milk total solids yield of $P_{\Pi}$ was higher than $P_{\mid}$and $P_{\| 1 \mid}$. The values of milk total solids $\%$ were 14.13 , 14.45 , and 14.44 (g/head/day) for $P_{1}, P_{\Pi}$ and $P_{\| I}$, respectively. Also, there are significant differences for both milk SNF \%, milk SNF yield, milk TP \%, milk TP yield, milk lactose \%, milk lactose yield, milk ash \% and milk ash yield between periods of lactation, where the values of milk solids not fat $\%$ and milk solids not fat yield of $\mathrm{P}_{\|}$were higher than and $\mathrm{P}_{\mid}$and $\mathrm{P}_{\|}$.

\section{Milk radical scavenging activity}

There are no significant differences $(p>0.05)$ for antioxidant activity between the tested rations Table (5), where the $R_{3}$ recorded the highest antioxidant activity followed by $R_{2}$ then $R_{4}$ and finally control $\left(R_{1}\right)$. These results are agreement with those obtained by Shabtay et al., (2012) who indicated that the milk from cows fed pomegranate peel extract was higher antioxidant activity than the control, where hydrolyzable tannins have been shown to positively relationship with antioxidant activity and polyphenol content in pomegranate peel and juice (Gil et al., 2000; Tzulker et al., 2007) and In pomegranate, hydrolyzable tannins include punicalin, ellagic acid, gallagic acid and punicalagin (Gil et al., 2000). Punicalagin has high lipid peroxidation-inhibitory and radical-scavenging activities (Kulkarni et al., 2004), and its health promoting attributes may be of relevance to the health of the animal which consume it (Adams et al., 2006). So, encourage use of milk enriched with antioxidants in human diets to promote human health and prevent diseases associated with oxidative stress, including cancers (Serrano et al., 1998).

\section{Feed intake and feed conversion}

There are no significant differences for dry matter and energy intake (SV, and TDN) of the tested rations Table (6), while the values of DCP intake were higher significantly $(P<0.05)$, for $R_{3}$ and $R_{2}$ followed by $R_{4}$ then $R_{1}$. These results are agreement with those obtained by Safari et al., (2018) and Kotsampasi et al., (2017) who reported that there is no effect of the addition of pomegranate peel in the diet on dry matter intake, Also, Saeed et al., (2017) indicated that the diet lambs containing low level (1.5\%) of PP was higher nitrogen intake compared to the control.

There were no significant differences were detected in feed conversion of DM, SV, TDN, and DCP between the tested rations Table (6). Regarding feed conversion of DM, SV, and TDN, R4 was insignificantly superior to the other tested rations followed by R3 then R1. Ration two (R2) was the worst one regarding feed conversion. Safari et al., (2018) concluded that milk efficiency of dairy cow fed diet containing pomegranate seed and peel was similar across the control ration.

\section{Some blood serum parameters}

No significant differences were found between the tested rations for serum total protein, albumin and globulin Table (7), where all values of them were within the normal range $(6.1-7.5,2.3-3.6$ and $2.7-4.4$ 
$\mathrm{g} / \mathrm{dl}$, respectively) as found by Boyd (2011). Generally no changes in the blood metabolites (serum albumin, total protein and globulin) suggested that damage to the liver did not occur. These results are an agreement with Hatami et al., (2018) who found that the addition of PEG to the PP diets has no effect on plasma albumin and total protein concentration. However, Safari et al., (2018) indicated that the level of albumin and total protein was lower for cows fed pomegranate by-products than control during postpartum. Also, Khan et al., (2015) found that no significant difference was found in total protein level between control and groups fed PP, while was found increased in albumin level in tested groups compared to the control.

The result indicated that the differences between rations for serum urea and creatinine Table (7) were not significant. The values of serum urea and creatinine were within the normal range $(10-50 \mathrm{mg} / \mathrm{dl})$ as reported by Kaneko (1989) and (0.7-1.5 mg/dl) as noticed by Boyd (2011), respectively. Such finding may suggest no negative effect on goat kidneys. Also, it was clear that no significant differences were obtained regarding serum glucose Table (7) of goat fed $R_{1}, R_{2}$, and $R_{3}$, but there are significant differences between $\mathrm{R}_{4}$ and other tested rations. The values of serum glucose of the tested rations were within the normal range (48-76 mg/dl) as observed by Boyd (2011).

Table (7) showed no significant changes in AST and ALT levels and the values of serum AST and ALT were within the normal range (8-40 and 5-30 Unit/dl, respectively) according to (Kaneko, 1989), which indicated the healthy effect of tested additives to goat's diets, where serum levels of AST and ALP are those conventionally used for domestic animal hepatic damagem, Specifically, ALP is used to detect bile obstruction, i.e. mild and progressive damage to the liver (Silanikove and Tiomkin, 1992), whereas liver enzymes like ALT, which is a liver specific hepatocellular enzyme released by hepatocellular damage, is used to assess liver damage (Mahgoub et al., 2008). These results of serum AST and ALT were similar to those obtained by Hatami et al., (2018) who found that the addition of PEG to the PP diets has no effect on plasma AST and ALT concentration. However, Safari et al., (2018) indicated that the level of AST was lower for cows fed pomegranate by-products than control during postpartum. Also, Ramzi, (2016) indicated that the level of AST was highest in lambs fed PP than the control, while ALT level was highest in lambs of the control compared to groups that fed PP in the diet. Such differences may support the effect of animal breed.

There were no significant differences among all groups in the overall means of serum cholesterol, triglyceride, HDL, LDL, and LDL/HDL ratio Table (7). The obtained results of lipid profiles were similar to Hussein and Shujaa (2013b) they reported that the addition of PP in the diet of Awassi had no effect on cholesterol, and triglyceride concentration. On the other hand, Safari et al., (2018) indicated that the level of cholesterol was lower for cows fed pomegranate by-products than control during postpartum, and Khan et al., (2015) found that total cholesterol and HDL concentration in lambs fed 1\% PP were decreased, while triglyceride, LDL concentration, and LDL/HDL ratio increased compared to control group.

\section{Simple economical evaluation of the tested rations}

Ration two $\left(R_{2}\right)$ had higher net revenue and relative percentage of net revenue compared with other tested rations Table (8). The cost of feed consumed for $R_{3}$ was higher than the other tested rations because of the price of polyethylene glycol was higher, Moreover, $R_{3}$ showed negatively net revenue. Finally $R_{2}$ was the best one. 


\section{Conclusion}

It seems that the rations containing pomegranate peel $\left(R_{2}\right)$, and pomegranate peel with polyethylene glycol) $R_{3}$ ) could be used successfully for lactating goats since it improved feed intake, nutrients digestibility, milk yield and composition, but $R_{3}$ is very expensive compared with control one from economical point of view, $\mathrm{R}_{3}$ showed negatively economical effect and not recommended.

\section{Declarations}

The contributions made by each listed author:

Abdelkader Kholif was supervised the work, made statistical analysis and publishing the manuscript.

Gamal Eldeen Aboulfotouh was supervised the work in the farm, methodology and wrote the manuscript the manuscript,

Ola Gamal A. Hassan works in the farm, labs, , and wrote the manuscript the manuscript.

Abdelalim M. Abd El-Mola was supervised the work in labs. methodology and review of the original draft

All authors read and approved the manuscript.

\section{Ethics declarations}

\section{Statement of animal right}

The research was conducted in accordance with applicable international, national and institutional guidelines for the care and use of animals

\section{Declaration of competing interest}

The authors report no declarations of interest.

\section{The data was available to provide.}

\section{References}

1. Abarghuei, M.J., Rouzbehan, Y., Salem, A.Z.M. and Zamiri, M.J. 2013. Nutrient digestion, ruminal fermentation and performance of dairy cows fed pomegranate peel extract. Livest. Sci. 157, 452-461.

2. Abedo, A. A., Hafez, Y. H., Khalifa, E. I., Mohamed, Bahera, K, and El-Zolaky, O. A. 2013. Milk Yield and Composition Of Dairy Zaraibi Goats Fed Microbial Inoculated Corn Silage. Egyptian Journal of Sheep and Goat Sciences, 8 (1): 141-151.

3. Adams, L.S., Seeram, N.P., Aggarwal, B.B., Takada, Y., S. and, D., Heber, D. 2006. Pomegranate juice, total pomegranate ellagitannins, and punicalagin suppress inflammatory cell signaling in colon cancer cells. J. Agric. Food Chem. 54, 980-985. 
4. Addisu Sh. 2016. Effect of dietary tannin source feeds on Ruminal fermentation and production of cattle; a review. Online J. Anim. Feed Res., 6(2): 45-56.

5. Alphonsus, C. and Essien, I.C. 2012. The relationship estimates amongst milk yield and milk composition characteristics of Bunaji and Friesian× Bunaji cows. Afr. J. Biotechnol. 11(36): 8790-8793.

6. AOAC 2009. Official method of analysis. 18th Ed., Association of Official Analytical Chemists, Washington, DC.

7. Boyd, J.W. 2011. The interpretation of serum biochemistry test results in domestic animal, In: Veterinary Clinical Pathology, Merck Sharp \& Dohme Corp., a subsidiary of Merck \& Co., Inc.

8. Brand-Williams, W., Cuvelier, M.E. and Berset, C. 1995. Use of a free radical method to evaluate antioxidant activity. Lebensm. Wiss. Technol. 28(1): 25-30.

9. Central Agency for Public Mobilization and Statistics. 2019. Annual Bulletin Of Statistical Crop Area And Plant Production. No. 71-22122-2017.Cairo, Egypt.

10. Christaki, E.V., Bonos, E.M. and Florou-Paneri, P.C. 2011. Dietary benefits of pomegranates in humans and animals. J. Food Agric. Environ. 9, 142-144.

11. Delavar, M.H., Tahmasbi, A.M., Danesh-Mesgaran, M. and Valizadeh, R. 2014. In vitro rumen fermentation and gas production: influence of different by-product feedstuffs. Annual Research \&Review in Biology.4(7), 1121-1128.

12. Duncan, D.B. 1955. Multiple range and multiple F tests. Biometrics, 1:11.

13. Ebrahimi, B. 2012. Evaluation of pomegranate pomace using gas production technique.European Journal of Experimental Biology; 2 (3), 853- 854.

14. Eliyahu, D., Shaani, Y., Yosef, E., Ben-Meir, Y., Nikbachat, M., Solomon, R., Mabjeesh, S.J., Weinberg, Z.G, and Miron, J. 2015. Effect of ensiling pomegranate pulp with solid additives on chemical composition, intake and digestibility by sheep. Small Rumin. Res. 131, 93-98.

15. Farag, M.A.A.M. 1979. Milk productions from local breeds of sheep. M.Sc. Thesis, Faculty of Agriculture, Zagazig University.

16. Gaines, W. L. 1928. The energy basis of measuring energy milk in dairy cows. Univ. Illinois Agric.

17. Gil, M. I., Tomas-Barberan, F. A., Hess-Pierce, B., Holcroft, D. M. and Kader, A. A. 2000. Antioxidant activity of pomegranate juice and its relationship with phenolic composition and processing. J. Agric. Food Chem. 48, 4581-4589.

18. Goering, H. K. and Van Soest, P. J. 1970. Forage Fiber Analysis (Apparatus, Reagents, Procedures and Some Applications). USDA. Agricultural handbook, Washington, DC, 379 p.

19. HamaKhan, K.M., Hamasalim, H.J., Sadq, S.M. and Ramzi, D.O.M. 2015. Changes in lipid profile and some blood biochemical parameters in Karadi lambs receiving different levels of pomegranate peels. Research Opinions in Animal and Veterinary Sciences. 5, 210-214.

20. Hatami, A., Alipour, D., Hozhabri, F, and Tabatabaei, M. 2018. Effect of different levels of pomegranate marc with or without polyethylene glycol on performance, nutrients digestibility and protozoal population in growing lambs. Animal Feed Science and Technology. 235, 15-22. 
21. Hussein, S.A.M. and Shujaa, T.A. 2013a. The effect of using different ratios of pomegranate peels in performance and digestibilities in Awassi lambs. Journal of Tikrit University for Agricultural Sciences, 13, 52-62.

22. Hussein, S.A.M and Shujaa, T.A . 2013b. The effect of using different ratios of pomegranate peels powder on performance and some blood characteristics in Awassi Lambs. J.Tikrit Univ.Agric.Sci. 13, 255-265.

23. Jami, E., Shabtay, A., Nikbachat, M., Yosef, E., Miron, J. and Mizrahi, I. 2012. Effects of adding a concentrated pomegranate-residue extract to the ration of lactating cows on in vivo digestibility and profile of rumen bacterial population. Journal of Dairy Science. 95:5996-6005.

24. Kaneko, J.J. 1989. Clinical Biochemistry of Domestic animals $4^{\text {th }}$ ed., Academic Press, Inc. (U.S.A).

25. Khan, K.M.H, Hamasalim, H.J., Sadq, S.M and Ramzi, D.O.M. 2015. Changes in lipid profile and some blood biochemical parameters in Karadi lambs receiving different levels of pomegranate peels. Res Opin Anim Vet Sci. 5(5), 210-214.

26. Karamnejad, K., Sari, M., Salari, S, and Cha, M. 2019. Effects of nitrogen source on the performance and feeding behavior of lambs fed a high concentrate diet containing pomegranate peel. Small Ruminant Research; 173: 9-16.

27. Kotsampasi, B., Christodoulou, C., Tsiplakou, E., Mavrommatis, A., Mitsiopoulou, C., Karaiskou, C., Dotas, V., Robinson, P.H. Bampidis, V.A. Christodoulou, V, and Zervas, G. 2017. Effects of dietary pomegranate pulp silage supplementation on milk yield and composition, milk fatty acid profile and blood plasma antioxidant status of lactating dairy cows. Animal Feed Science and Technology, 234, 228-236.

28. Kulkarni, A.P., Aradhya, S.M. and Divakar, S. 2004. Isolation and identification of a radical scavenging antioxidant-punicalagin from pith and carpellary membrane of pomegranate fruit. Food Chem. 87, 551-557.

29. Kushwaha, S. C., Bera, M. B. and Kumar, Pradyuman 2013. Nutritional composition of detanninated and fresh pomegranate peel powder. Journal of Environmental Science, Toxicology and Food Technology, $7(1), 38-42$.

30. Mahgoub, O., Kadim, IT., Tageldin, MH., Al-Marzooqi, WS., Khalaf, SQ, and Ambu Ali, A. 2008. Clinical profifi le of sheep fed non-conventional feeds containing phenols and condensed tannins. Small Rum Res, 78: 115-122.

31. Makkar, H.P.S., Blummel M., Borowy, N.K., and Becker, K. 1993. Gravimetric determination of tannins and their correlations with chemical and protein precipitation methods. J. Sci. Food Agric.61,161-165.

32. Mars, M. and Marrakchi, M. 1999. Diversity of pomegranate (Punica granatum L.) germplasm in Tunisia. Genet. Resour. Crop. Evolution; 46(5),461-467.

33. McNabb, W.C., Waghorn, G.C., Peters, J.S, and Barry, T.N. 1996. The Effect of Condensed Tannins in Lotus pedunculatus on the Solubilisation and Degradation of Ribulose-1,5-bisphosphate Carboxylase (EC 4.1.1.39; Rubisco) Protein in the Rumen and the Sites of Rubisco Digestion. British Journal of Nutrition, 76, 535-549.

34. Miguel, G.M., Neves, A.M. and Antunes, D.M. 2010. Pomegranate (Punica granatum L.): A medicinal plant with myriad biological properties - A short review. J. Med. Plants Res, 4(25),2836-2847. 
35. Mirzaei-Aghsaghali. A., Maheri-Sis, N., Mansouri, H., Razeghi, M. E., Mirza-Aghazadeh, A., Cheraghi, H. and Aghajanzadeh-Golshani, A. 2011. Evaluating potential nutritive value of pomegranate processing by-products for ruminants using in vitro gas production technique.ARPN J. Agric. Biol. Sci, 6, 45-51.

36. NRC 1985. Nutrient requirement of sheep. National Academy of Science, National Research council. Ashington, D.C., USA.

37. Patra, A.K., and Saxena, J. 2011. Exploitation of Dietary Tannins to Improve Rumen Metabolism and Ruminant Nutrition. Journal of the Science of Food and Agriculture, 91, 24-37.

38. Prakash, A., Mathur, K., Vishwakarma, A., Vuppu, S., and Mishra, B. 2013. Comparative assay of antioxidant and antibacterial properties of Indian culinary seasonal fruit peel extracts obtained from Vellore, Tamilnadu. International Journal of Pharmaceutical Sciences Review and Research,19, 131135.

39. Prakash, C.V.S. and Prakash, I. 2011. Bioactive chemical constituents from pomegranate (Punicagranatum) juice, seed and peel- A Review. Int J Res Chem Environ, 1, 1-18.

40. Ramzi, D.O.M. 2016. Effect of different ratios of pomegranate peels on hematological, biochemical parameters and reproductive hormones of karadi ram lambs. Inter J Vet Sci, 5(1): 19-23.

41. Saeed, A., Abdulridha, Elaf., Ali, Zahraa., Mohsen, M. and Fathel, M. 2017. Effect of addition of different levels of pomegranate peel powder to concentrate diet on productive performance of Awassi lambs. QJVMS. 16 :(3) 6th Conference (1st international) 27-28 Sep.

42. Safari, M., Ghasemi, E., Alikhani, M, and Ansari-Mahyari, S. 2018. Supplementation effects of pomegranate by-products on oxidative status, metabolic profile, and performance in transition dairy cows. J. Dairy Sci., 101,1-13.

43. Sadq, S.M., Ramzi, D.O.M., Hamasalim, H.J. and Ahmed, K.A. 2015. Growth performance and digestibility in karadi lambs receiving different levels of pomegranate peels. Open Journal of Animal Sciences, 5, 16-23.

44. Sestili, P., Martinelli, C., Ricci, D., Fraternale, D., Bucchini, A., and Giamperi, L. 2007. Cytoprotective effect of preparations from various parts of Punica granatum L. fruits in oxidatively injured mammalian cells in comparison with their antioxidant capacity in cell free systems. Pharmacological Research; 56: 1826.

45. Serrano, A., Palacios, C., Roy, G., Cespón, C., Villar, M., Nocito, M. and González-Porqué, P. 1998. Derivatives of gallic acid induce apoptosis in tumoral cell lines and inhibit lymphocyte proliferation. Arch. Biochem. Biophys. 350, 49-54.

46. Shaani, Y., Eliyahu, D., Mizrahi, I., Yisef, E., Ben-Meir, Y., Nikbachat, M., Solomon, R., Mabjeesh, S.J., and Miron, J. 2015. Effect of feeding ensiled mixture of pomegranate pulp and drier feeds on digestibility and milk performance in dairy cows. J. Dairy Res., 83, 35-41.

47. Shabtay, A., Nikbachat, M., Zenou, A., Yosef, E., Arkin, O., Sneer, O., Shwimmer, A., Yaari, A., Budmand, E., Agmond, G. and Miron, J. 2012. Effects of adding a concentrated pomegranate extract to the ration of lactating cows on performance and udder health parameters. Anim. Feed Sci. Technol. 175:24-32.

48. Silanikove, N, and Tiomkin, D. 1992. Toxicity induced by poultry litter consumption: effect on parameters reflecting liver function in beef cows. Anim Prod, 54: 203-209. 
49. Silanikove, N., Nitsan, Z. and Perevolotsky, A. 1994. Effect of a daily supplementation of polyethylene glycol on intake and digestion of tannin-containing leaves (Ceratonia siliqua) by sheep. J. Agric. Food Chem,42, 2844-2847.

50. Silanikove, N., Shinder, D., Gilboa, N., Eyal, M. and Nitsan, Z. 1996. Binding of Poly (ethylene glycol) to Samples of Forage Plants as an Assay of Tannins and Their Negative Effects on Ruminal Degradation. J Agric. Food Chem., 44(10):3230-3234.

51. SPSS 2007. Statistical Package for Social Science, SPSS Inc., Chicago, IL, USA Copyright@ for Windows, version 16.0 .

52. Taher-Maddah, M., Maheri-Sis, N., Salamatdoustnobar, R. and Ahmadzadeh, A. 2012. Estimating fermentation characteristics and nutritive value of ensiled and dried pomegranate seeds for ruminants using in vitro gas production technique.Open Veterinary Journal, 2, 40-45.

53. Titus, C. H., F. D. Provenza, A. Perelovotsky, N. Silaniokove, and J. Rogosic. 2001. Supplemental polyethylene glycol influences preferences of goats browsing blackbrush. J. Range Manage., 54,161165.

54. Tzulker, R., Glazer, I., Bar-llan, I., Holland, D., Aviram, M. and Amir, R. 2007. Antioxidant activity, polyphenol content, and related compounds in different fruit juices and homogenates prepared from 29 different pomegranate accessions. Journal of Agricultural and Food Chemistry, 55, 9559-9570.

55. Van Keulen, J.V . and Young, B.A. 1977. Evaluation of acid insoluble ash as a natural marker in ruminant digestibility studies. J. Anim. Sci., 44, 282.

56. Waghorn, G.C. and Mcnabb, W.C. 2003. Consequences of plant phenolic compounds for productivity and health of ruminants. Proc. Nutr., Soc. 62, 383-392.

\section{Tables}

Table (1): Chemical composition of feed ingredients that used in the tested rations (\%). 


\begin{tabular}{|c|c|c|c|c|c|}
\hline \multirow[t]{2}{*}{ Item } & \multicolumn{5}{|c|}{ Ingredient } \\
\hline & CFM & EC & WS & PP & DPP \\
\hline DM & 87.56 & 93.54 & 92.36 & 90.85 & 96.75 \\
\hline OM & 83.46 & 78.27 & 73.04 & 87.21 & 84.12 \\
\hline $\mathrm{CP}$ & 16.45 & 18.39 & 4.11 & 4.84 & 5.89 \\
\hline EE & 2.08 & 4.50 & 0.91 & 4.69 & 1.62 \\
\hline CF & 4.18 & 16.14 & 32.62 & 15.53 & 18.87 \\
\hline NFE & 60.76 & 39.24 & 35.39 & 62.15 & 57.72 \\
\hline Ash & 4.10 & 15.27 & 19.32 & 3.64 & 12.64 \\
\hline NDF & 11.50 & 49.45 & 57.53 & 20.58 & 30.10 \\
\hline ADF & 5.16 & 40.99 & 49.76 & 19.46 & 29.17 \\
\hline ADL & 1.20 & 12.40 & 12.18 & 7.68 & 12.09 \\
\hline Hemicelluloses & 6.33 & 8.47 & 7.75 & 1.11 & 1.82 \\
\hline Cellulose & 3.96 & 28.58 & 37.57 & 11.78 & 17.07 \\
\hline Lignin & 0.53 & 10.32 & 5.66 & 4.15 & 6.89 \\
\hline Tannins & - & - & -- & 15.28 & 14.65 \\
\hline
\end{tabular}

(CFM): Concentrates feed mixture, (EC): Egyptian clover, (WS): Wheat straw, (PP): Pomegranate peel and (DPP): Detanninated pomegranate peel.

Table (2): Digestibility coefficients and nutritive values of the tested rations (on DM basis \%) 


\begin{tabular}{|c|c|c|c|c|c|}
\hline \multirow[t]{2}{*}{ Item } & \multicolumn{4}{|c|}{ Tested rations } & \multirow[t]{2}{*}{ \pm SE } \\
\hline & $\mathrm{R}_{1}$ & $\mathbf{R}_{2}$ & $\mathbf{R}_{3}$ & $\mathbf{R}_{\mathbf{4}}$ & \\
\hline \multicolumn{6}{|c|}{ Digestibility coefficients \%: } \\
\hline DM & 72.26 & 72.64 & 72.62 & 70.72 & 0.39 \\
\hline OM & 73.90 & 74.49 & 73.94 & 71.72 & 0.45 \\
\hline $\mathrm{CP}$ & 70.15 & 71.62 & 71.77 & 69.93 & 0.50 \\
\hline EE & $56.73^{b}$ & $66.89^{a}$ & $64.41^{a}$ & $62.99^{a}$ & 1.35 \\
\hline CF & 60.99 & 61.63 & 61.78 & 58.19 & 0.64 \\
\hline NFE & 79.63 & 79.48 & 78.63 & 76.66 & 0.48 \\
\hline \multicolumn{6}{|l|}{ Nutritive values: } \\
\hline TDN, \% & 59.97 & 60.74 & 60.23 & 58.44 & 0.37 \\
\hline$S V, \%$ & 52.78 & 53.48 & 52.99 & 51.22 & 0.36 \\
\hline DCP, \% & 9.71 & 9.92 & 9.94 & 9.68 & 0.07 \\
\hline $\mathrm{DE}, \mathrm{MCal} / \mathrm{kg}^{*}$ & 2.64 & 2.68 & 2.66 & 2.58 & 0.02 \\
\hline ME, MCal/kg * & 2.22 & 2.25 & 2.23 & 2.15 & 0.02 \\
\hline $\mathrm{NE}_{\mathrm{L}}, \mathrm{MCal} / \mathrm{kg}^{*}$ & 1.35 & 1.37 & 1.36 & 1.31 & 0.01 \\
\hline
\end{tabular}

Average in the same row having different superscripts are differ significantly $(P \leq 0.05)$ for $a$, and $b$.

*calculated according to NRC (1985), DE: 0.04409*TDN, ME: 1.01*DM-0.45 and NE ${ }_{\mathrm{L}}: 0.0245 *$ TDN-0.12

$\mathbf{R}_{\mathbf{1}}$ : Control: $50 \%$ CFM $+25 \%$ Egyptian clover and $25 \%$ wheat straw, $\mathbf{R}_{\mathbf{2}}: \mathbf{R}_{\mathbf{1}}+1 \%$ pomegranate peel, $\mathbf{R}_{\mathbf{3}}: \mathbf{R}_{\mathbf{1}}+$ $1 \%$ pomegranate peel $+20 \mathrm{~g}$ Polyethylene glycol (PEG) and $\mathbf{R}_{\mathbf{4}}: \mathbf{R}_{\mathbf{1}}+1 \%$ detanninated pomegranate peel.

Table (3): Overall mean values of milk yield and composition for the tested rations of lactating goat: 


\begin{tabular}{|c|c|c|c|c|c|}
\hline \multirow[t]{2}{*}{ Item } & \multicolumn{5}{|c|}{ Treatments } \\
\hline & $\mathrm{R}_{1}$ & $\mathbf{R}_{\mathbf{2}}$ & $\mathbf{R}_{\mathbf{3}}$ & $\mathbf{R}_{\mathbf{4}}$ & \pm SE \\
\hline Milk yield (g/h/day) & $842.33^{a}$ & $844.56^{\mathrm{a}}$ & $851.78^{a}$ & $808.22^{b}$ & 15.19 \\
\hline Fat corrected (4\%) milk yield & 800.58 & 756.52 & 827.25 & 823.53 & 13.90 \\
\hline Fat $\%$ & $3.68^{b c}$ & $3.33^{c}$ & $3.83^{\mathrm{ab}}$ & $4.16^{\mathrm{a}}$ & 0.10 \\
\hline TS\% & $14.24^{\mathrm{bc}}$ & $14.11^{\mathrm{c}}$ & $14.39^{a b}$ & $14.62^{\mathrm{a}}$ & 0.07 \\
\hline SNF\% & 10.55 & 10.78 & 10.56 & 10.46 & 0.08 \\
\hline TP\% & 3.96 & 4.04 & 3.96 & 3.92 & 0.03 \\
\hline Lactose \% & 5.72 & 5.84 & 5.72 & 5.67 & 0.04 \\
\hline Ash\% & 0.88 & 0.90 & 0.88 & 0.87 & 0.01 \\
\hline Fat yield $(\mathrm{g})$ & 30.91 & 27.91 & 32.44 & 33.35 & 0.74 \\
\hline TS yield $(g)$ & 120.03 & 119.28 & 122.42 & 118.16 & 2.24 \\
\hline SNF yield $(\mathrm{g})$ & $89.12^{\mathrm{a}}$ & $91.37^{a}$ & $89.98^{a}$ & $84.81^{b}$ & 2.07 \\
\hline TP yield $(\mathrm{g})$ & $33.42^{\mathrm{a}}$ & $34.26^{\mathrm{a}}$ & $33.74^{a}$ & $31.81^{\mathrm{b}}$ & 0.78 \\
\hline Lactose yield (g) & $48.27^{a}$ & $49.49^{a}$ & $48.74^{\mathrm{a}}$ & $45.94^{b}$ & 1.12 \\
\hline Ash yield (g) & $7.43^{a}$ & $7.61^{\mathrm{a}}$ & $7.50^{\mathrm{a}}$ & $7.07^{b}$ & 0.17 \\
\hline
\end{tabular}

Average in the same row having different superscripts are differ significantly $(P<0.05)$ for $a, b$ and $c$. TS: total solids, SNF: solids not fat and TP: total protein

Table (4): Overall mean values of milk yield and composition in the different lactation periods: 


\begin{tabular}{|c|c|c|c|c|}
\hline \multirow[t]{2}{*}{ Item } & \multicolumn{4}{|c|}{ Treatments } \\
\hline & $P_{1}$ & $P_{\|}$ & $\mathbf{P}_{\mathrm{III}}$ & $\pm S E$ \\
\hline Total milk yield ( $\mathrm{g} / \mathrm{h} /$ day) & $833.00^{\mathrm{b}}$ & $941.83^{\mathrm{a}}$ & $735.33^{c}$ & 0.85 \\
\hline fat corrected $(4 \%)$ milk yield & $819.18^{a}$ & $850.35^{a}$ & $736.38^{b}$ & 9. 34 \\
\hline Fat $\%$ & $3.89^{a}$ & $3.35^{\mathrm{b}}$ & $4.01^{\mathrm{a}}$ & 0.14 \\
\hline TS\% & $14.13^{b}$ & $14.45^{\mathrm{a}}$ & $14.44^{\mathrm{a}}$ & 0.12 \\
\hline SNF\% & $10.24^{\mathrm{b}}$ & $11.09^{a}$ & $10.43^{b}$ & 0.10 \\
\hline TP\% & $3.84^{b}$ & $4.16^{\mathrm{a}}$ & $3.91^{b}$ & 0.04 \\
\hline Lactose \% & $5.55^{\mathrm{b}}$ & $6.01^{\mathrm{a}}$ & $5.65^{\mathrm{b}}$ & 0.05 \\
\hline Ash\% & $.85^{\mathrm{b}}$ & $.92^{\mathrm{a}}$ & $87^{b}$ & 0.01 \\
\hline Fat yield (g) & 32.40 & 31.57 & 29.48 & 1.26 \\
\hline TS yield $(\mathrm{g})$ & $117.70^{b}$ & $136.05^{a}$ & $106.17^{c}$ & 1.46 \\
\hline SNF yield (g) & $85.30^{\mathrm{b}}$ & $104.48^{\mathrm{a}}$ & $76.69^{c}$ & 1.15 \\
\hline TP yield $(\mathrm{g})$ & $31.99^{b}$ & $39.18^{a}$ & $28.76^{c}$ & 0.43 \\
\hline Lactose yield (g) & $46.20^{\mathrm{b}}$ & $56.59^{a}$ & $41.54^{\mathrm{C}}$ & 0.62 \\
\hline Ash yield (g) & $7.11^{\mathrm{b}}$ & $8.71^{\mathrm{a}}$ & $6.39^{c}$ & 1.10 \\
\hline
\end{tabular}

Average in the same row having different superscripts are differ significantly $(P<0.05)$ for $a, b$ and c. $\mathbf{P}_{\mathrm{I}}$ : First period of lactation, $\mathbf{P}_{\mathrm{II}}$ Second period of lactation and $\mathbf{P}_{\mathrm{III}}$ : Third period of lactation. TS: total solids, SNF: solids not fat and TP: total protein

Table (5): Effect of the tested rations on milk radical scavenging activity of lactating goat.

\begin{tabular}{|lll|}
\hline Tested rations & Inhibition \% & Remaining of ${ }^{\mathrm{DPPH}} \%$ \\
\hline $\mathbf{R}_{\mathbf{1}}$ & 14.36 & 85.64 \\
\hline $\mathbf{R}_{\mathbf{2}}$ & 17.01 & 82.99 \\
\hline $\mathbf{R}_{\mathbf{3}}$ & 17.34 & 82.66 \\
\hline $\mathbf{R}_{\mathbf{4}}$ & 15.65 & 84.35 \\
\hline $\mathbf{S E}$ & 0.52 & 0.52 \\
\hline
\end{tabular}


*DPPH (1, 1 diphenyl 2, picryl hydrazyl)

Table (6): Effect of the tested rations on daily feed intake and feed conversion of lactating goats:

\begin{tabular}{|c|c|c|c|c|c|}
\hline \multirow[t]{2}{*}{ Item } & \multicolumn{4}{|c|}{ Tested rations } & \multirow[t]{2}{*}{ \pm SE } \\
\hline & $\mathbf{R}_{1}$ & $\mathbf{R}_{\mathbf{2}}$ & $\mathbf{R}_{3}$ & $\mathbf{R}_{\mathbf{4}}$ & \\
\hline \multicolumn{6}{|l|}{ Feed intake } \\
\hline $\mathrm{DM}, \mathrm{Kg}$ & 1.40 & 1.41 & 1.43 & 1.41 & 0.003 \\
\hline TDN, Kg & 0.81 & 0.83 & 0.83 & 0.78 & 0.007 \\
\hline SV, Kg & 0.71 & 0.73 & 0.73 & 0.68 & 0.007 \\
\hline $\mathrm{DCP}, \mathrm{g}$ & $121.59^{b}$ & $135.25^{a}$ & $137.10^{a}$ & $127.52^{\mathrm{ab}}$ & 2.25 \\
\hline \multicolumn{6}{|l|}{ Feed conversion } \\
\hline DM/FCM, kg/kg & 1.76 & 1.88 & 1.74 & 1.72 & 0.04 \\
\hline SV/FCM, kg/kg & 1.02 & 1.11 & 1.01 & 0.95 & 0.02 \\
\hline TDN/ FCM, kg/kg & 0.89 & 0.97 & 0.88 & 0.83 & 0.02 \\
\hline DCP/ FCM , $g / g$ & 0.15 & 0.18 & 0.17 & 0.16 & 0.004 \\
\hline
\end{tabular}

Average in the same row having different superscripts are differ significantly $(P<0.05)$ for $a$ and $b$.

Table (7): Effect of the tested rations on some blood serum parameters of lactating goats: 


\begin{tabular}{|c|c|c|c|c|c|c|}
\hline \multirow[t]{2}{*}{ Items } & \multicolumn{4}{|c|}{ Rations } & \multirow[t]{2}{*}{ $\pm S E$} & \multirow[t]{2}{*}{ Normal range } \\
\hline & $\mathrm{R}_{1}$ & $\mathbf{R}_{\mathbf{2}}$ & $\mathbf{R}_{3}$ & $\mathbf{R}_{\mathbf{4}}$ & & \\
\hline Total protein, g/dl & 7.30 & 7.23 & 7.23 & 7.40 & 0.05 & $6.1-7.5$ \\
\hline Albumin, $\mathrm{g} / \mathrm{dl}$ & 3.33 & 3.37 & 3.5 & 3.37 & 0.08 & $2.3-3.6$ \\
\hline Globulin, g/dl & 3.97 & 3.86 & 3.73 & 4.03 & 0.08 & $2.7-4.4$ \\
\hline Urea, mg/dl & 29.67 & 28.67 & 29.00 & 28.00 & 0.7 & $10-50$ \\
\hline Creatinine, $\mathrm{mg} / \mathrm{dl}$ & 0.76 & 0.67 & 0.7 & 0.66 & 0.03 & $0.7-1.5$ \\
\hline Glucose, mg/dl & $61^{a}$ & $61.67^{a}$ & $63^{a}$ & $43^{b}$ & 2.7 & $48-76$ \\
\hline AST,IU/dl & 11.03 & 11.87 & 10.20 & 10.60 & 0.32 & $8-40$ \\
\hline ALT, IU/dl & 16.33 & 16.67 & 17 & 19.33 & 0.61 & $5-30$ \\
\hline cholesterol, mg/dl & 97.67 & 101.67 & 103.67 & 97.67 & 1.08 & - \\
\hline Triglyceride, mg/dl & 62.33 & 65.00 & 65.33 & 64.33 & 2.08 & - \\
\hline $\mathrm{HDL}, \mathrm{mg} / \mathrm{dl}$ & 42.67 & 45.33 & 49 & 45.33 & 1.06 & - \\
\hline $\mathrm{LDL}, \mathrm{mg} / \mathrm{dl}$ & 42.53 & 43.33 & 41.53 & 39.47 & 0.57 & - \\
\hline LDL/HDL ratio & 1.00 & 0.96 & 0.85 & 0.87 & 0.03 & - \\
\hline
\end{tabular}

Average in the same row having different superscripts are differ significantly $(P<0.05)$ for $a$ and $b$.

Table (8): Simple economical evaluation of the tested rations of lactating goats:

\begin{tabular}{|c|c|c|c|c|}
\hline \multirow[t]{2}{*}{ Item } & \multicolumn{4}{|l|}{ Rations } \\
\hline & $\mathrm{R}_{1}$ & $\mathrm{R}_{2}$ & $\mathrm{R}_{3}$ & $\mathrm{R}_{4}$ \\
\hline Milk yield (kg/head/90d) & 75.81 & 76.01 & 76.66 & 72.74 \\
\hline $\begin{array}{l}\text { Dry matter } \\
\text { consumed }(\mathrm{kg} / \mathrm{head} / 90 \mathrm{~d})\end{array}$ & 126 & $127.26(126+1.26)$ & $129.06(126+1.26+1.8)$ & $127.26(126+1.26)$ \\
\hline $\begin{array}{l}\text { Price of one } \mathrm{kg} \text { DM of } \\
\text { the ration, L.E. }\end{array}$ & 3.25 & $(3.25+0.007)$ & $(3.25+0.007+19)$ & $(3.25+0.007)$ \\
\hline $\begin{array}{l}\text { Cost of feed consumed } \\
\text { (L.E /head/90d). }\end{array}$ & 409.5 & 410.13 & 2120.13 & 410.13 \\
\hline *Total revenue, L.E & 530.67 & 532.07 & 536.62 & 509.18 \\
\hline$\star \star$ Net revenue, L.E & 121.17 & 121.94 & -1583.51 & 99.05 \\
\hline $\begin{array}{l}\text { Relative percentage of } \\
\text { net revenue }\end{array}$ & 100 & 100.64 & -1306.85 & 81.74 \\
\hline
\end{tabular}


*, Total revenue, L.E= Milk yield ( $\mathrm{kg} / \mathrm{head} / 90 \mathrm{day}) \times 7.0 \mathrm{~L} . \mathrm{E}$ (price of one $\mathrm{kg}$ goats milk).

**, Net revenue, $($ L.E./h/90d) = Total revenue (L.E./h/90d) - Cost of feed consumed (L.E./h/90d), LE= Egyptian pound. 